\title{
RESPONSE OF SWISS CHARD AND SOIL PROPERTIES TO CO-APPLICATION OF DIFFERENT FERTILISERS WITH EFFECTIVE MICROORGANISMS
}

\author{
NCUBE, L. ${ }^{1 *}-$ ZHAO, B. ${ }^{1}-$ BRUTSCH, M-O. ${ }^{2}-$ VAN NIEKERK, H-J. ${ }^{1}$ \\ ${ }^{1}$ College of Agriculture and Environmental Sciences, Department of Environmental Sciences \\ P.O. Box 392, UNISA 003, South Africa \\ fax:+27-(011)-471-2866 \\ ${ }^{2}$ University of Fort Hare, Faculty of Science and Agriculture, Department of Agronomy \\ P.O. Box X1314, Alice, South Africa \\ *Corresponding author \\ e-mail: lindyncube@yahoo.co.uk,ncubel@unisa.ac.za; phone: +27-725-523-711 \\ (Received 23 $3^{\text {rd }}$ Feb 2017; accepted $19^{\text {th }}$ May 2017)
}

\begin{abstract}
The use of mineral fertilisers causes soil degradation; however, there are alternative systems such as the application of effective microorganisms (EM), although this technology is not fully studied in Africa. The objective of this greenhouse experiment was to assess the response of Swiss chard (Beta vulgaris subsp. cicla) and soil chemical properties to EM. The crop was harvested twice - after eight and sixteen weeks. The experimental design was randomised complete block design, treatments were: control, $\mathrm{EM}$, recommended fertilizer $(\mathrm{RF}), \mathrm{RF}+\mathrm{EM}$, compost, compost + EM, 1/2 RF + compost, 1/2 RF + compost + EM, goat manure $(\mathrm{GM}), \mathrm{GM}+\mathrm{EM}, 1 / 2 \mathrm{RF}+\mathrm{GM}$, and $1 / 2 \mathrm{RF}+\mathrm{GM}+\mathrm{EM}$, with six replications and each pot represented an experimental unit. The first yield was higher than the yield from the second harvest, except for the GM treatments due to nitrogen immobilisation. Yield was improved by $32.5 \%$ for the second harvest where GM was applied owing to improved nutrient availability. The application of fertiliser doubled the yields, which were not reduced when half of the recommended fertiliser was applied with GM or compost. The results confirm that EM's application had inconsistent effects on Swiss chard yields and soil properties.
\end{abstract}

Keywords: Beta vulgaris subsp. cicla, mineral fertiliser, organic manure, effective microorganisms, soil properties

\section{Introduction}

The use of effective microorganisms (EM) in agricultural soils as an amendment for disease control and maintenance of healthy resilient soils was reported by Daly and Stewart (1999), and Hu et al. (2013). EM are a microbial culture of a naturally occurring assortment of beneficial microorganisms such as photosynthetic bacteria (Rhodopseudomonas plastris and Rhodobacter sphacrodes), lactic acid bacteria (Lactobacillus plantarum, L. casei, and Streptococcus lactis), yeast (Saccharomyces spp), actinomycetes (Strptomyces spp.) and fermenting fungi that coexist together (Bell et al., 2013; Hu and Qi, 2013; Boga et al., 2014; Daur et al., 2015). EM are used as an inoculant to increase the microbial biomass diversity of soils through a rapid proliferation of their constituents (Javaid and Bajwa, 2011; Bhalla et al., 2013; Khan et al., 2013). Application of EM solution to soils enhances the growth of other microorganisms and a colony forming units (CFU) of 110000000 per gram on TS agar has been recorded (Javaid and Bajwa, 2011).

EM improve crop quality, growth and yield through effective mineralisation of soil organic matter (Megali et al., 2014; Daur, 2015, 2016; Xu et al., 2016) and are applied 
with a carbon and energy source of molasses for the microorganisms (Mayer et al., 2010; Ahn et al., 2014). The integrated use of EM with organic amendments is an effective technique for enhancing nutrient release and supply from the sources. The mechanism of EM activities for rapid nutrient release from organic amendments involves a rapid proliferation of its effective and beneficial microorganism content within the soil system (Bouws and Finckh, 2008; Gabhane et al., 2012).

Some studies have shown that the inoculation of soils with EM can improve soil and crop quality (Javaid and Bajwa, 2011; Megali et al., 2014; Javaid and Bajwa, 2016). Research and field testing of EM were conducted in the Asia Pacific region (Bajwa et al., 1995; Bajwa et al., 1999; Hussain et al., 1999; Iwaishi, 2000; Hu and Qi, 2013; Daur, 2015, 2016; Xu et al., 2016), Switzerland (Mayer et al., 2010; Megal et al., 2013), Africa (Ncube et al., 2011; Ncube and Brutsch, 2012) and New Zealand (Daly and Stewart, 1999) where the application of EM to onions, peas and sweet corn increased yields by $29 \%, 31 \%$ and $23 \%$, respectively. Khaliq et al. (2006) reported that the integrated use of compost with EM increased seed cotton by $44 \%$ over the control treatment. The application of EM with $50 \mathrm{Mg} \mathrm{ha}^{-1}$ of animal manure and $30 \mathrm{mg} \mathrm{ha}^{-1}$ of a combination of various green crop residues and weeds separately, increased the production of polysaccharides, alkaline phosphatase and esterase enzymes (Valarini et al., 2002). The application of compost A with EM resulted in the highest strawberry yield and quality (Hammad et al., 2014). In a study conducted by Megali et al. (2014), application of EM increased plant growth fruit production by $61 \%$ and plants sustained $25 \%$ higher insect survival.

EM are effective in improving plant and soil quality, but studies conducted at the University of Fort Hare (Ncube et al., 2011; Ncube and Brutsch, 2012) did not detect a substantial contribution to crop yield by the recommended application of EM in combination with commercial compost. This was attributed to the low-quality $\mathrm{C}$ constituents in the compost used, which is typical of most compost that have matured. Composted organic wastes are low in soluble $\mathrm{C}$, because microorganisms use most of it during the composting process (Groenestein and van Faassen, 1996; Boechat et al., 2013). Therefore, mature compost such as the one used in the earlier study may not be able to effectively support proliferation of the decomposer community, including EM.

The objective of the study was to evaluate the single and integrated application of EM with fresh and composted organic sources of nutrients on the yield of Swiss chard (Beta vulgaris subsp. cicla) grown in Oakleaf soil in pots.

\section{Materials and methods}

\section{Soil, goat manure and the compost characteristics}

The soil used in this study was from the research farm of the University of Fort Hare in Alice, Eastern Cape, South Africa. The farm is located at $32^{\circ} 47^{\prime} \mathrm{S}$ and $26^{\circ} 50^{\prime} \mathrm{E}$ and $535 \mathrm{~m}$ above sea level (asl.). The farm is situated in a semi-arid ecological zone that has an average annual rainfall of approximately $575 \mathrm{~mm}$ during the summer and a mean daily temperature of $22.5^{\circ} \mathrm{C}$ during the day and $18.8^{\circ} \mathrm{C}$ at night. In winter the temperatures are about $13.6^{\circ} \mathrm{C}$ during the day and below $10.3^{\circ} \mathrm{C}$ at night (Marais and Brutsch, 1994). The soils are of an Oakleaf form (Oa), belonging to the Jozini series (Soil Working Group, 1991). The soil characteristics are as shown in Table 1. An equivalent of $30 \mathrm{t} \mathrm{ha}^{-1}$ of goat manure was applied (which supplied 657, 30, $135 \mathrm{~kg} \mathrm{ha}^{-1}$ of $\mathrm{N}$, phosphate $(\mathrm{P})$, and potassium $(\mathrm{K})$, respectively) (Table 1). Thirty $\mathrm{t} \mathrm{ha}^{-1}$ of nature's 
grow compost were applied (which supplied 60, 15 and $12 \mathrm{~kg} \mathrm{ha}^{-1}$ of $\mathrm{N}, \mathrm{P}$, and $\mathrm{K}$, respectively) (Table 1).

Table 1. Selected properties of the experimental soil (upper $0-30 \mathrm{~cm}$ depth), goat manure and compost

\begin{tabular}{|c|c|c|c|}
\hline Characteristics & Soil & Goat manure & Compost \\
\hline pH (1:2.5 soil: water) & 6.1 & 8.0 & 4.3 \\
\hline $\mathrm{EC}\left(\mu \mathrm{Scm}^{-1}\right)$ & 90.0 & 2.2 & 2.4 \\
\hline $\mathrm{CEC}_{\text {sum }}(\mathrm{meq} / 100 \mathrm{~g}) \dagger$ & 12.1 & - & - \\
\hline Exchangeable acidity $(\mathrm{cmol} / \mathrm{L})$ & 0.1 & - & - \\
\hline Total cations $(\mathrm{cmol} / \mathrm{L})$ & 12.1 & - & - \\
\hline Total $\mathrm{N}\left(\mathrm{g} \mathrm{kg}^{-1}\right)$ & 0.6 & 21.9 & 3.2 \\
\hline Total $\mathrm{P}\left(\mathrm{g} \mathrm{kg}^{-1}\right)$ & - & 1.0 & 0.5 \\
\hline Available $\mathrm{P}\left(\mathrm{g} \mathrm{kg}^{-1}\right)$ & 0.4 & - & - \\
\hline Total $\mathrm{K}\left(\mathrm{g} \mathrm{kg}^{-1}\right)$ & 5.0 & 4.5 & 0.4 \\
\hline Exchangeable $\mathrm{K}\left(\mathrm{g} \mathrm{kg}^{-1}\right)$ & 0.1 & - & - \\
\hline Exchangeable $\mathrm{Ca}\left(\mathrm{g} \mathrm{kg}^{-1}\right)$ & 1.7 & - & - \\
\hline Exchangeable $\mathrm{Mg}\left(\mathrm{g} \mathrm{kg}^{-1}\right)$ & 0.3 & - & - \\
\hline Total C $\left(\mathrm{g} \mathrm{kg}^{-1}\right)$ & 9.4 & 426.3 & 96.65 \\
\hline Organic $\mathrm{C}\left(\mathrm{g} \mathrm{kg}^{-1}\right)$ & 6.0 & - & - \\
\hline $\mathrm{C}: \mathrm{N}$ & 16.5 & 19.5 & 30.2 \\
\hline $\mathrm{C}: \mathrm{P}$ & - & 426.3 & 386.6 \\
\hline
\end{tabular}

$\dagger \mathrm{CEC}$ is cation exchange capacity, and EC is electrical conductivity

\section{Treatments and experimental design}

The experiment was conducted in a glasshouse whose conditions are controlled at the University of Fort Hare, South Africa, and was laid as a randomised complete block (RCB) with six replicates. Treatments were: control (T1), EM alone (EM) (T2), recommended fertiliser (RF) (N 150: $\mathrm{P} 90 \mathrm{~kg} \mathrm{ha}^{-1}$ ) (T3), RF + EM (T4), compost (Comp) (T5), comp + EM (T6), 1/2 RF (N 75: P $\left.45 \mathrm{~kg} \mathrm{ha}^{-1}\right)+$ comp (T7), 1/2 RF + comp + EM (T8), goat manure (GM) (T9), GM + EM (T10), 1/2 RF + GM (T11) and $1 / 2 \mathrm{RF}+\mathrm{GM}+\mathrm{EM}(\mathrm{T} 12)$. Two plants of Swiss chard were planted in each pot with a depth of $30 \mathrm{~cm}$ containing $15 \mathrm{~kg}$ of soil as an individual experimental unit. The soil moisture was kept at field capacity during the course of the experiment. Swiss chard was used in this study due to an increasing awareness on the importance of leafy vegetables in the daily diet which has prompted an increasing demand for the fresh vegetable crops such as Swiss chard throughout the year in South Africa (AbdelRahman et al., 2014). Moreover, Swiss chard is known for its high nutritional value due to its high levels of antioxidants and vitamins (Mitic et al., 2013). The crop was harvested at the eighth and the sixteenth week. Inorganic fertiliser was incorporated into the soil, with $\mathrm{N}$ applied in the form of NPK prior to planting and as LAN three weeks after transplanting.

\section{Effective microorganisms (EM)}

Multiplied - EM, EM - F.P.E, EM 3-in-1 and EM -5 were the EM products used. The Multiplied-EM was dissolved in water in a ratio of 1:300 and applied as a soil drench at a rate of $200 \mathrm{~L}$ per experimental unit, 7 days prior to transplanting of Swiss chard. 
During the experiment, multiplied - EM solution, in a ratio of 1: 500, was applied to respective EM - treated units at a rate of $50 \mathrm{~L}$ per week. Mixtures of EM - FPE, EM 3in-1 and EM - 5, mixed at a ratio of 1: 1: 1, then diluted with water at a ratio of 1: 800 were sprayed to control diseases and pests in EM treated units (Ncube et al., 2011).

\section{Soil and leaf analysis}

Soil and leaf samples were taken at harvest to assess the treatment effects on soil and plant nutrient content. For leaf sampling, the youngest mature leaves were taken from the top of plants (Hue et al., 2012). The leaf dry matters were dried in an oven at $65^{\circ} \mathrm{C}$ and were ground in a hammer mill to pass through a $1 \mathrm{~mm}$ mesh sieve. Total $\mathrm{P}$ and $\mathrm{K}$ contents were determined as described by Okalebo et al. (2002). Total nitrogen was determined using a LECO TruSpec C/N auto analyser (LECO Corporation, 2003).

Crude protein is an estimate for total protein. Crude Protein $(\mathrm{CP})$ is based on a laboratory nitrogen analysis, from which the total protein content can be calculated by multiplying the nitrogen figure by $100 / 16$ or 6.25 . This is from the assumption that nitrogen is derived from protein containing $16 \%$ nitrogen (Okalebo et al., 2002). Therefore, crude protein was calculated by multiplying total $\mathrm{N} \times 6.25$.

Soil samples were air-dried for two weeks and then were ground to pass through a 2 $\mathrm{mm}$ mesh sieve. Soil $\mathrm{pH}$ and EC were determined in water extracts as described by Okalebo et al. (2002). Total $\mathrm{N}$ and $\mathrm{C}$ were determined using a LECO TruSpec C/N auto analyser (LECO Corporation, 2003) and extractable P and K were determined following the Ambic - 2 extraction method (Non-Affiliated Soil Analysis Work Committee, 1990).

\section{Data analysis}

The data were subjected to analysis of variance (ANOVA) using the SAS statistical package and means were compared with Tukey test $(\mathrm{p} \leq 0.05)$.

\section{Results and discussion}

\section{Effects of amendments on dry matter yield of Swiss chard}

Yield obtained during the second harvest was lower than yield obtained during the first harvest. Yield decreased by $46.2 \%, 44.2 \%, 51.3 \%, 56.6 \%, 44.1 \%, 44.3 \%, 68.0 \%$, $67 \%, 43.3 \%$ and $57.9 \%$ for $\mathrm{T} 1, \mathrm{~T} 2, \mathrm{~T} 3, \mathrm{~T} 4, \mathrm{~T} 5, \mathrm{~T} 6, \mathrm{~T} 7, \mathrm{~T} 8, \mathrm{~T} 11$ and $\mathrm{T} 12$, respectively (Figure 1). The application of goat manure with or without EM significantly increased yield for the second harvest. An increase in yield of $61.3 \%$ and $84.3 \%$ for the second harvest was observed with T9 and T10 relative to the control (Figure 1). The positive effects of incorporating goat manure with or without EM observed during the second cropping suggests that soil production was better maintained under goat manure treatment, possibly as a result of nutrients being slowly released over a period of time as suggested by Cooke (1972; Neina et al., 2016a). Application of goat manure to soil decreases nutrients sorption capacity and increases their availability to plants. This is thought to result from the cumulative effects of various processes such as preliminary soil incubation, soil microbial activities, moisture content, incubation temperature, soil $\mathrm{pH}, \mathrm{N}$ mineralisation and ammendment biochemistry. The immobilisation of nutrients by native soil microbial biomass in response to added manure may also increase its availability to plants. Native microbial biomass apparently increases nutrients 
availability by immobilizing soil inorganic nutrients and releasing them at a later stage through mineralization during microbial biomass turnover. The nutrients is released slowly and taken up by the crop more efficiently and may account, at least in part, for the observed synergistic effects on crop growth observed (Gichangi et al., 2010; Calvalho et al., 2013; Neina et al., 2016b). Therefore, nutrients contained in manure are primarily organic and must be mineralised before they are used by plants.

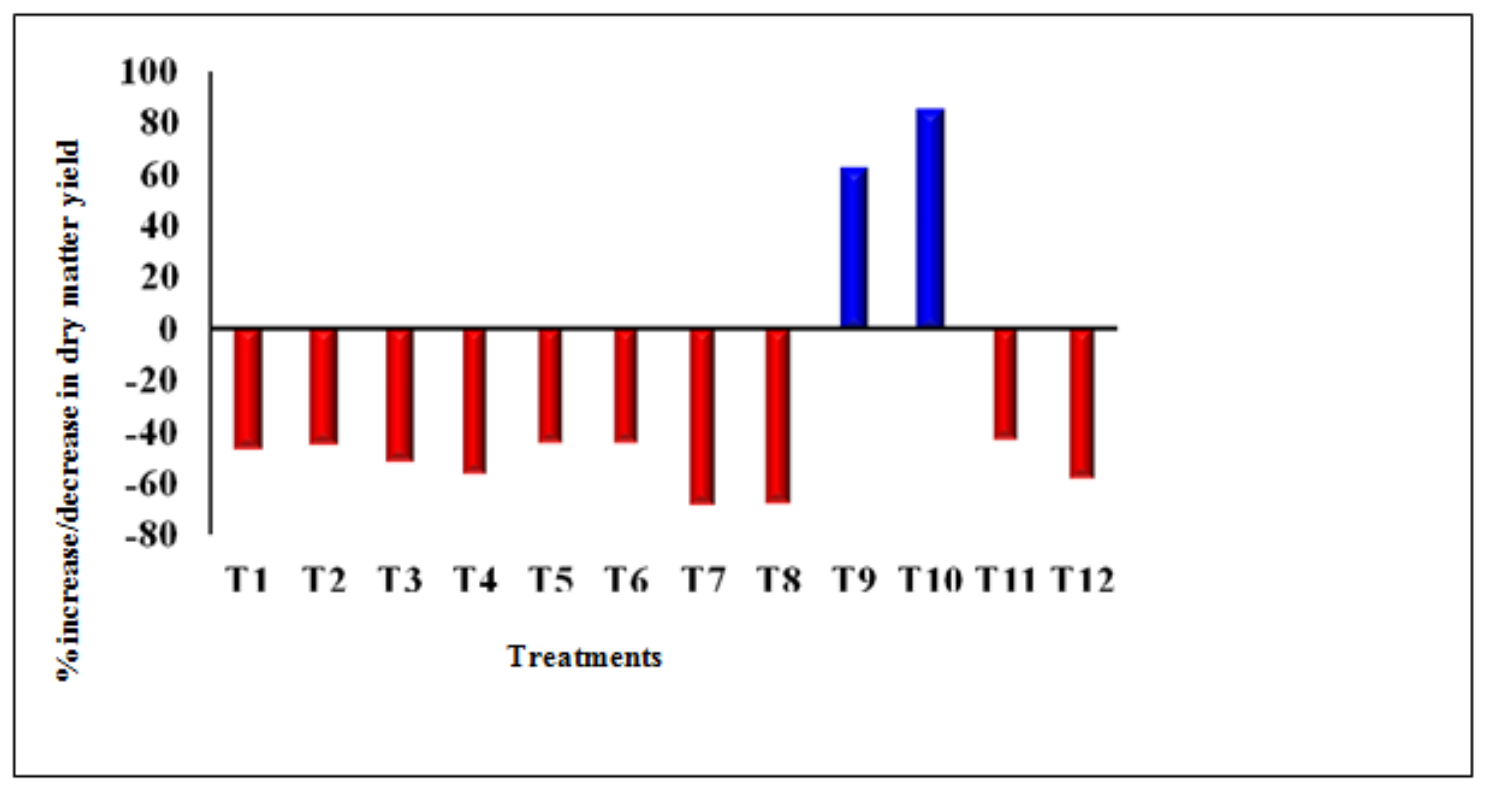

Figure 1. Effects of amendments on dry matter yield of Swiss chard

T1: control, T2: effective microorganisms, T3: reference fertiliser, T4: reference fertiliser + EM, T5: compost alone, T6: compost + effective microorganisms, T7: half reference fertiliser + compost, T8: half reference fertiliser + compost + effective microorganisms, T9: goat manure alone, T10: goat manure + effective microorganisms, T11: half reference fertiliser + goat manure, T12: goat manure + half reference fertiliser + effective microorganisms

The performance of EM and compost was not as expected when applied alone or in combination (Figure 2) and their performance was speculated to have been affected by the soil organic $\mathrm{C}$, which was low $(0.6 \%)$. In soils with low organic $\mathrm{C}$, release of nutrients from compost materials is relatively low and cannot increase yield to the same level as the mineral fertilisers. The added compost in soils with low organic $\mathrm{C}$ could be first utilised by native soil microbes, as plants and microbes compete for applied $\mathrm{N}$ (Khaliq et al., 2006). Unlike microbes, plants require more energy for nutrient absorption and uptake so that microorganisms become successful in utilising most of the applied $\mathrm{N}$. The release of nutrients from compost materials, their absorption by plants and the remineralisation of immobilised nutrients require time and might not be attained within a few weeks (Hussain et al., 1999).

With regards to the performance of EM, researchers have shown that it is difficult to establish the predominance of EM cultures in soil within a few weeks. Indigenous soil microbes often affect the establishment of EM negatively (Bajwa et al., 1995). However, the problem can be overcome through prolonged, repeated applications of EM (Javaid et al., 2000). Soil type, the source and amount of soil nutrients, as well as the test crop can also affect the establishment and performance of EM (Bajwa et al., 
1999; Javaid et al., 2002; Javaid, 2010). In a 4-year field experiment under organic management (2003-2006) in Zurich, Switzerland, application of EM did not improve yields and soil quality (Mayer et al., 2010).

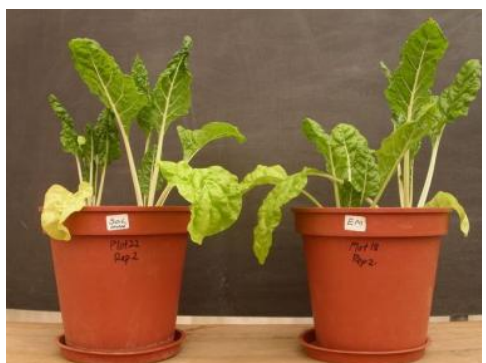

A

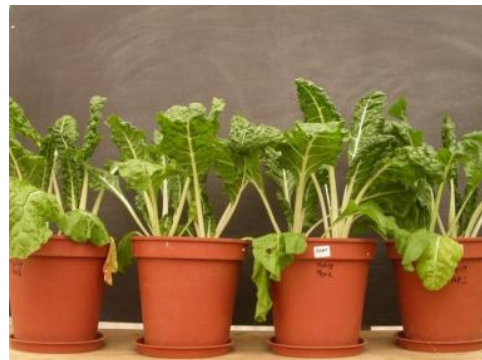

D

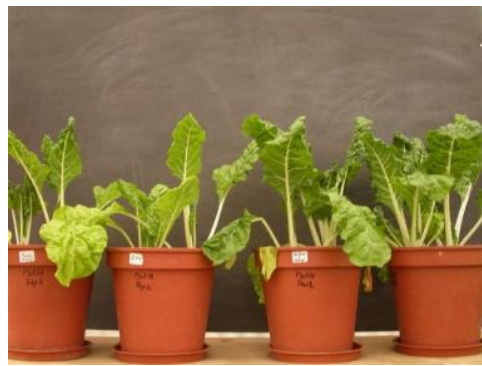

G

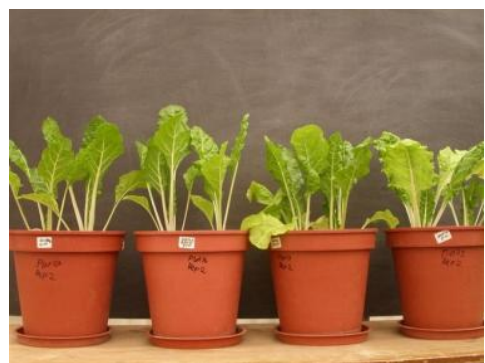

B

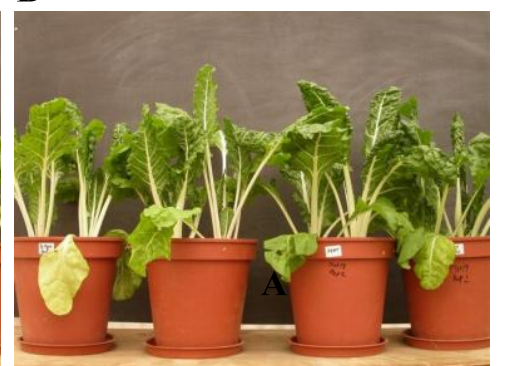

$\mathbf{E}$

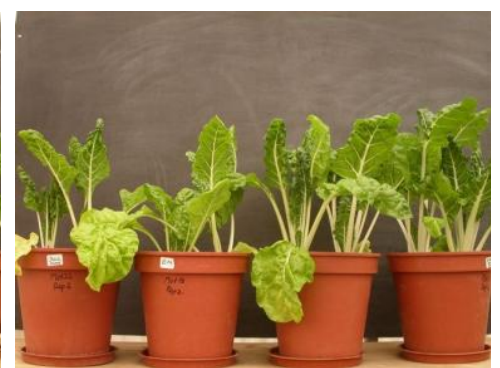

H

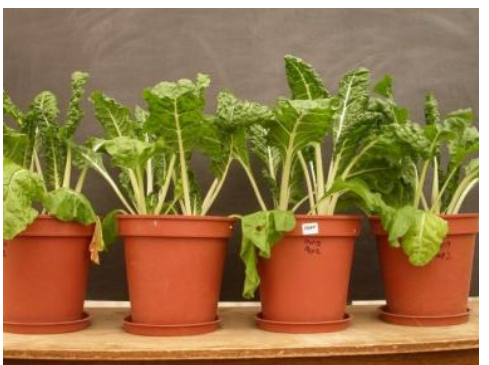

C

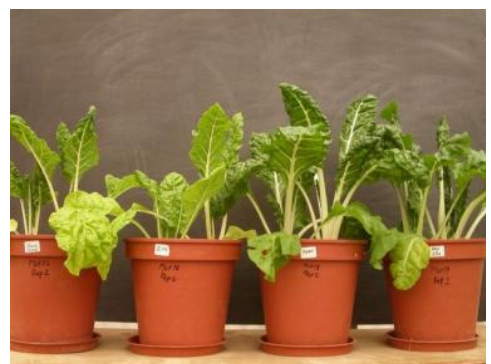

$\mathbf{F}$

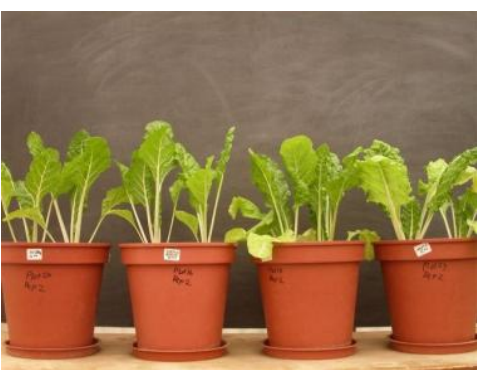

I

Figure 2. Swiss chard plants growing in the greenhouse

$\boldsymbol{A}=$ Control and EM, $\boldsymbol{B}=1 / 2$ Reference Fertilizer $+G M+E M, G M+E M$ and Comp $+E M, \boldsymbol{C}$

$=G M, G M+E M$, Reference Fertilizer and Reference Fertilizer $+E M, D=1 / 2$ Reference

Fertilizer + Comp, 1/2 Reference Fertilizer + GM, Reference Fertilizer and Control, $\boldsymbol{E}=1 / 2$

Reference Fertilizer + GM, GM, Reference Fertilizer and Control, $\boldsymbol{F}=$ Control, EM, Reference Fertilizer and Reference Fertilizer $+E M, \boldsymbol{G}=$ Control, EM, 1/2 Reference Fertilizer + Comp, 1/2

Reference Fertilizer + Comp $+E M, \boldsymbol{H}=$ Control, EM, GM and Comp, $\boldsymbol{I}=G M, G M+E M$,

Comp, Comp + EM

The application of the reference fertilisers (T3 and T4) caused a significant increase in yield for both the first and the second harvests (Figure 3), possibly due to the immediate release of nutrients from the added reference fertiliser. The application of T7, T8, T11 and T12 resulted in yield that was equivalent to that obtained with the application of the reference fertiliser (T3 and T4). These results indicate that half of the required mineral fertilisers can substitute half of the required fertiliser amount, possibly because of greater amounts of $\mathrm{N}$ and $\mathrm{P}$ supplied to the soil. Similar results were obtained by Khaliq et al. (2006), where the application of $\mathrm{OM}+\mathrm{EM}+1 / 2$ mineral NPK 
yielded $2091 \mathrm{~kg} \mathrm{ha}^{-1}$ of seed compared to $2165 \mathrm{~kg} \mathrm{ha}^{-1}$ obtained from the recommended mineral NPK.

It is noteworthy that yield obtained from the control and treatments other than goat manure declined in the second harvest (Figure 3). This could be attributed to a decline in nutrient content as a result of nutrient removal by the first crop. The removal of nutrients by the first crop is confirmed by higher levels of leaf $\mathrm{N}$ content and subsequent $\mathrm{N}$ uptake by the first crop compared to the second crop (Table 2). Leaf $\mathrm{P}$ content increased during the second cropping and this ruled out the possibility of $\mathrm{P}$ limiting plant growth during the second cropping. These results are similar to those obtained by Tanner and Mugwira (1984). In their study, the application of manure to soil resulted in an increase in nutrient uptake by the second crop rather than the immediate crop. The implication of these results is that farmers should take measures to ensure that nutrients in organic material become available before plants begin their rapid development. Similar results were also obtained by Zhao et al. (2014).

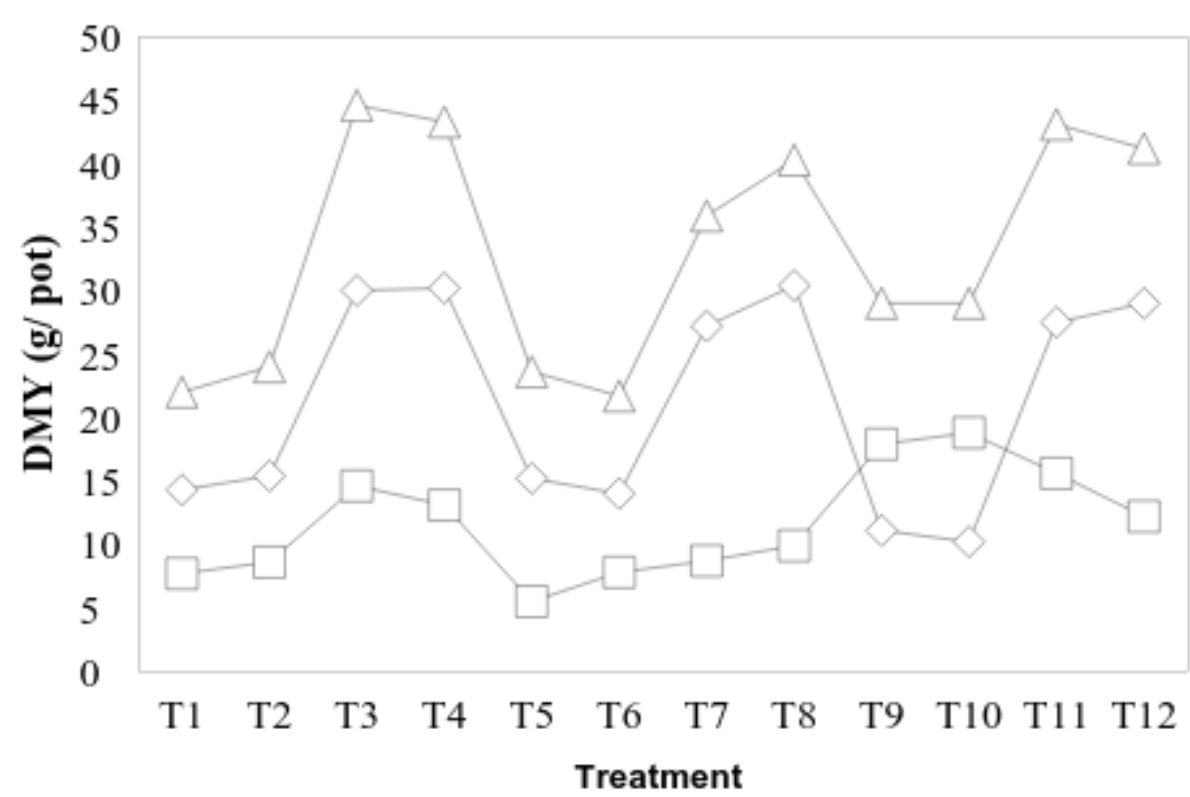

Fist Harvest Second harvest - Total yield

Figure 3. Effects of amendments on Swiss chard dry matter yield (DMY) T1: control, T2: effective microorganisms, T3: reference fertiliser, T4: reference fertiliser + EM, T5: compost alone, T6: compost + effective microorganisms, T7: half reference fertiliser + compost, T8: half reference fertiliser + compost + effective microorganisms, T9: goat manure alone, T10: goat manure + effective microorganisms, T11: half reference fertiliser + goat manure, T12: goat manure + half reference fertiliser + effective microorganisms

\section{Effects of amendments on leaf nutrient content}

Leaf nutrient contents is a good predictor of plant responses to nutrients supplied through soil applied fertilisers. Nutrient management in organically managed soils is fundamentally different to soils managed conventionally, however, the underlying processes supporting soil fertility are not. This suggests that, although soil fertility is theoretically better in organic management, if there is a balanced supply of nutrients, i.e. there are no deficiencies or excesses of a nutrient that cause excessive consumption, the plant will take the nutrients in proportion to their needs (Herencia and Maqueda, 2016). 
There were significant $(\mathrm{p} \leq 0.05)$ treatment effects on leaf $\mathrm{N}$ content of both harvests (Table 2). Leaf $\mathrm{N}$ content ranged from $1.34 \mathrm{~g} \mathrm{~kg}^{-1}$ to $3.79 \mathrm{~g} \mathrm{~kg}^{-1}$ in the first harvest and 1.12 to $1.73 \mathrm{~g} \mathrm{~kg}^{-1}$ in the second harvest. The application of reference fertiliser significantly increased leaf $\mathrm{N}$ content of both the first and the second harvests as compared to the control. The highest leaf $\mathrm{N}$ concentration was observed with respect to the application of the reference fertiliser with EM in both the first and the second harvests. The application of half the reference fertiliser with compost resulted in a significant increase (18\%) in leaf $\mathrm{N}$ content as compared to the control in the first harvest. Nitrogen is a critical component of proteins and biomolecules such as chlorophyll in plants (Fu et al., 2017). A similar trend was observed with respect to leaf $\mathrm{N}$ uptake, with the highest leaf $\mathrm{N}$ uptake being observed with reference fertiliser + EM treatment in both harvests. Due to the close relationship between $\mathrm{N}$ and protein, a similar trend was observed with crude protein in both harvests.

Leaf $\mathrm{P}$ content ranged from $0.06 \mathrm{~g} \mathrm{~kg}^{-1}$ to $0.14 \mathrm{~g} \mathrm{~kg}^{-1}$ in the first harvest and from $0.10 \mathrm{~g} \mathrm{~kg}^{-1}$ to $0.25 \mathrm{~g} \mathrm{~kg}^{-1}$ in the second harvest. Leaf $\mathrm{P}$ content remarkably increased from a depressed state in the first harvest to a significantly higher figure in the second harvest. The application of goat manure caused a significant $(p \leq 0.05)$ increase in leaf $P$ content relative to the control treatment (Table 2). It is known that with the addition of organic nutrients, the supply and availability of $\mathrm{P}$ is high in soils (Herencia et al., 2008). Manure application rates are routinely based on crop $\mathrm{N}$ requirements, which might have resulted in more $\mathrm{P}$ than is needed by the crop and this can cause a buildup of $\mathrm{P}$ in the soil (Edmeades, 2003) and consequently in plants. The P/N relationships for adequate crop development are usually 1/10 (Herencia and Maqueda, 2016), however, in the goat manure used in the current study, the P/N relationship was about 1/21.9. This amount would be in excess of the crop's needs. The application of goat manure with EM resulted in leaf $\mathrm{P}$ content that was significantly lower than that of the control.

\section{Effects of EM, goat manure, compost and mineral fertiliser on selected soil properties}

Post-cropping soil $\mathrm{pH}$ was significantly $(\mathrm{p} \leq 0.05)$ affected by different soil amendments (Table 3). The application of the reference fertiliser significantly depressed post-cropping $\mathrm{pH}$, which declined to levels that were moderately acidic (Table 3). A similar trend was observed with the application of half reference fertiliser with compost (T7) and half reference fertiliser with compost and EM (T8).

The application of goat manure alone (T9) or with half the reference fertiliser (T11), without or with EM (T12), significantly increased post-cropping soil $\mathrm{pH}$ relative to the control treatment. The highest post-cropping $\mathrm{pH}$ was observed with the sole application of goat manure (T9). These results indicate that goat manure has a liming effect, whereas the mineral fertiliser has acidifying effects. The liming effects of goat manure can be of great value in areas like the Eastern Cape, South Africa, parts of which have critically low soil pH (Mandiringana et al., 2005). Similar results were obtained by Mhlontlo et al. (2007), in whose study the application of sheep kraal manure at rates greater than $2.5 \mathrm{t} \mathrm{ha}^{-1}$ resulted in higher $\mathrm{pH}$ values compared to the control and the mineral fertiliser treatments. 
Table 2. Effects of amendments on leaf $N$ content, $N$ uptake, crude protein, $P$, and $K$ in Swiss chard plants

\begin{tabular}{|c|c|c|c|c|c|c|c|c|c|c|}
\hline \multirow[t]{2}{*}{ Treatments } & \multicolumn{5}{|c|}{ First harvest } & \multicolumn{5}{|c|}{ Second harvest } \\
\hline & $\mathrm{N}\left(\mathrm{g} \mathrm{kg}^{-1}\right)$ & $\begin{array}{l}\text { N uptake } \\
\left(\mathrm{mg} \mathrm{pot}^{-1}\right)\end{array}$ & $\begin{array}{l}\text { Crude } \\
\text { protein } \\
\left(\mathrm{g} \mathrm{kg}^{-1}\right)\end{array}$ & $\begin{array}{c}\mathrm{P} \\
\left(\mathrm{g} \mathrm{kg}^{-1}\right)\end{array}$ & $\begin{array}{c}\mathrm{K} \\
\left(\mathrm{g} \mathrm{kg}^{-1}\right)\end{array}$ & $\begin{array}{c}\mathrm{N} \\
\left(\mathrm{g} \mathrm{kg}^{-1}\right)\end{array}$ & $\begin{array}{l}\text { N uptake } \\
\left(\mathrm{mg} \mathrm{pot}^{-1}\right)\end{array}$ & $\begin{array}{l}\text { Crude } \\
\text { Protein } \\
\left(\mathrm{g} \mathrm{kg}^{-1}\right)\end{array}$ & $\begin{array}{c}\mathrm{P} \\
\left(\mathrm{g} \mathrm{kg}^{-1}\right)\end{array}$ & $\begin{array}{c}\mathrm{K} \\
\left(\mathrm{g} \mathrm{kg}^{-1}\right)\end{array}$ \\
\hline $\mathrm{T} 1$ & $2.3^{\mathrm{bc}}$ & $477.8^{\mathrm{ecd}}$ & $0.59^{b c}$ & $0.007^{\mathrm{bc}}$ & $1.24^{\mathrm{ab}}$ & $1.46^{\mathrm{ac}}$ & $150.0^{\mathrm{ab}}$ & $0.15^{\mathrm{bc}}$ & $0.25^{\mathrm{a}}$ & $0.89^{\mathrm{ab}}$ \\
\hline $\mathrm{T} 2$ & $1.3^{4 \mathrm{c}}$ & $200.0^{\mathrm{e}}$ & $0.33^{c}$ & $0.09^{\mathrm{abc}}$ & $1.15^{\mathrm{ab}}$ & $1.52^{\mathrm{ab}}$ & $223.35^{\mathrm{a}}$ & $0.08^{\mathrm{c}}$ & $0.22^{\mathrm{ab}}$ & $0.80^{\mathrm{b}}$ \\
\hline $\mathrm{T} 3$ & $3.0^{\mathrm{ab}}$ & $876.7^{\mathrm{ab}}$ & $0.75^{\mathrm{ab}}$ & $0.06^{\mathrm{c}}$ & $1.05^{\mathrm{b}}$ & $1.37^{\mathrm{cbd}}$ & $140.92^{\mathrm{ab}}$ & $0.19^{\mathrm{ab}}$ & $0.17^{\mathrm{bc}}$ & $0.84^{\mathrm{ab}}$ \\
\hline $\mathrm{T} 4$ & $3.8^{\mathrm{a}}$ & $1120.2^{\mathrm{a}}$ & $0.95^{\mathrm{a}}$ & $0.06^{\mathrm{c}}$ & $1.04^{\mathrm{b}}$ & $1.73^{\mathrm{a}}$ & $177.83^{\mathrm{ab}}$ & $0.24^{\mathrm{a}}$ & $0.21^{\mathrm{ab}}$ & $0.90^{\mathrm{ab}}$ \\
\hline T5 & $1.6^{\mathrm{c}}$ & $2389^{\text {ed }}$ & $0.40^{c}$ & $0.08^{\mathrm{abc}}$ & $1.15^{\mathrm{ab}}$ & $1.26^{\mathrm{cbd}}$ & $132.14^{\mathrm{ab}}$ & $0.10^{\mathrm{c}}$ & $0.24^{\mathrm{a}}$ & $0.90^{\mathrm{ab}}$ \\
\hline T6 & $1.4^{\mathrm{c}}$ & $192.5^{\mathrm{e}}$ & $0.35^{\mathrm{c}}$ & $0.07 b^{c}$ & $1.31^{\mathrm{ab}}$ & $1.29^{\mathrm{cbd}}$ & $152.36^{\mathrm{ab}}$ & $0.09^{c}$ & $0.22^{\mathrm{ab}}$ & $1.04^{\mathrm{ab}}$ \\
\hline $\mathrm{T} 7$ & $2.8^{\mathrm{ab}}$ & $757.0^{\mathrm{bc}}$ & $0.69^{\mathrm{ab}}$ & $0.06^{\mathrm{c}}$ & $1.31^{\mathrm{ab}}$ & $1.30^{\mathrm{cbd}}$ & $203.14^{\mathrm{ab}}$ & $0.17^{\mathrm{ab}}$ & $0.25^{\mathrm{a}}$ & $0.79^{\mathrm{b}}$ \\
\hline $\mathrm{T} 8$ & $2.9^{\mathrm{ab}}$ & $728.4^{\mathrm{bc}}$ & $0.71^{\mathrm{ab}}$ & $0.13^{\mathrm{ab}}$ & $1.21^{\mathrm{ab}}$ & $139^{\mathrm{cbd}}$ & $171.67^{\mathrm{ab}}$ & $0.18^{\mathrm{ab}}$ & $0.25^{\mathrm{a}}$ & $0.77^{\mathrm{b}}$ \\
\hline T9 & $1.6^{\mathrm{c}}$ & $180.8^{\mathrm{e}}$ & $0.41^{\mathrm{c}}$ & $0.10^{\mathrm{abc}}$ & $1.25^{\mathrm{ab}}$ & $1.12^{\mathrm{d}}$ & $157.34^{\mathrm{ab}}$ & $0.10^{\mathrm{c}}$ & $0.0^{\mathrm{d}}$ & $0.11^{\mathrm{a}}$ \\
\hline $\mathrm{T} 10$ & $2.0 b^{c}$ & $199.8^{\mathrm{e}}$ & $0.50^{\mathrm{bc}}$ & $0.14^{\mathrm{a}}$ & $1.27^{\mathrm{ab}}$ & $1.33^{\mathrm{cbd}}$ & $120.18^{b}$ & $0.12^{\mathrm{cb}}$ & $0.11^{\mathrm{cd}}$ & $0.91^{\mathrm{ab}}$ \\
\hline $\mathrm{T} 11$ & $1.7^{\mathrm{c}}$ & $482.3^{\text {ecd }}$ & $0.42^{\mathrm{c}}$ & $0.07^{\mathrm{bc}}$ & $1.21^{\mathrm{ab}}$ & $1.26^{\mathrm{cbd}}$ & $158.46^{\mathrm{ab}}$ & $0.10^{\mathrm{c}}$ & $0.19^{\mathrm{ab}}$ & $1.03^{\mathrm{ab}}$ \\
\hline $\mathrm{T} 12$ & $2.0^{\mathrm{bc}}$ & $560.8^{\text {bcd }}$ & $0.49^{\mathrm{bc}}$ & $0.06^{\mathrm{c}}$ & $1.39^{\mathrm{a}}$ & $1.23^{\mathrm{cd}}$ & $131.27^{\mathrm{ab}}$ & $0.12^{\mathrm{bc}}$ & $0.21^{\mathrm{ab}}$ & $0.91^{\mathrm{ab}}$ \\
\hline C.V & 32.64 & 47.924 & 32.64 & 47.53 & 18.09 & 14.21 & 38.64 & 32.64 & 23.02 & 22.10 \\
\hline
\end{tabular}

T1: control, T2: effective microorganisms, T3: reference fertiliser, T4: reference fertiliser + EM, T5: compost alone, T6: compost + effective microorganisms, T7: half reference fertiliser + compost, T8: half reference fertiliser + compost + effective microorganisms, T9: goat manure alone, T10: goat manure + effective microorganisms, T11: half reference fertiliser + goat manure, T12: goat manure + half reference fertiliser + effective microorganisms Means in a column with a different letter are statistically different (LSD test; $p \leq 0.05$ ). 
Table 3. The effects of amendments on selected soil properties after harvest of Swiss chard

\begin{tabular}{|c|c|c|c|c|c|c|c|}
\hline Treatment & $\begin{array}{c}\mathrm{pH} \\
(1: 2.5 \text { soil: water) }\end{array}$ & $\begin{array}{c}\mathbf{E C} \\
(\mu \mathrm{S} / \mathrm{cm})\end{array}$ & $\begin{array}{c}\mathbf{N} \\
\left(\mathrm{g} \mathrm{kg}^{-1}\right)\end{array}$ & $\begin{array}{l}\text { Total C } \\
\left(\mathrm{g} \mathrm{kg}^{-1}\right)\end{array}$ & C:N & $\begin{array}{c}\mathbf{P} \\
\left(\mathrm{g} \mathrm{kg}^{-1}\right)\end{array}$ & $\begin{array}{c}\mathrm{K} \\
\left(\mathrm{g} \mathrm{kg}^{-1}\right)\end{array}$ \\
\hline T1 & $5.7^{\mathrm{c}}$ & $9.7^{\mathrm{c}}$ & $0.5^{\mathrm{e}}$ & $7.4^{\mathrm{c}}$ & $13.2^{\mathrm{abc}}$ & $0.4^{\mathrm{g}}$ & $2.6^{\mathrm{d}}$ \\
\hline $\mathrm{T} 2$ & $5.7^{\mathrm{c}}$ & $10.6^{\mathrm{c}}$ & $0.6 \mathrm{~cd}^{\mathrm{e}}$ & $7.7^{\mathrm{c}}$ & $14.8^{\mathrm{a}}$ & $0.4^{\mathrm{g}}$ & $3.3^{\mathrm{cd}}$ \\
\hline $\mathrm{T} 3$ & $5.2^{\mathrm{e}}$ & $48.6^{\mathrm{a}}$ & $0.8^{\mathrm{ab}}$ & $7.8^{\mathrm{c}}$ & $14.8^{\mathrm{a}}$ & $1.1^{\mathrm{a}}$ & $2.8^{\mathrm{d}}$ \\
\hline $\mathrm{T} 4$ & $5.1^{\mathrm{e}}$ & $44.4^{\mathrm{a}}$ & $0.6^{\text {cde }}$ & $8.1^{\mathrm{bc}}$ & $12.7^{\mathrm{abc}}$ & $1.0^{\mathrm{ab}}$ & $2.0^{\mathrm{d}}$ \\
\hline $\mathrm{T} 5$ & $5.5^{\mathrm{cd}}$ & $10.1^{\mathrm{c}}$ & $0.6^{\text {cde }}$ & $8.3^{\mathrm{bc}}$ & $13.6^{\mathrm{abc}}$ & $0.4^{\mathrm{g}}$ & $3.1^{\mathrm{d}}$ \\
\hline T6 & $5.5^{\mathrm{cd}}$ & $10.1^{\mathrm{c}}$ & $0.5^{\mathrm{e}}$ & $7.7^{\mathrm{c}}$ & $14.1^{\mathrm{ab}}$ & $0.4^{\mathrm{g}}$ & $3.0^{\mathrm{d}}$ \\
\hline $\mathrm{T} 7$ & $5.2^{\mathrm{e}}$ & $28.7^{\mathrm{b}}$ & $0.7^{\text {bcde }}$ & $8.6^{\mathrm{bc}}$ & $11.8^{\mathrm{bc}}$ & $0.8^{\mathrm{cd}}$ & $2.8^{\mathrm{d}}$ \\
\hline $\mathrm{T} 8$ & $5.3^{\mathrm{de}}$ & $27 .^{3 \mathrm{~b}}$ & $0.8^{\mathrm{ab}}$ & $10.2^{\mathrm{a}}$ & $11.4^{\mathrm{c}}$ & $0.7^{\mathrm{de}}$ & $2.0^{\mathrm{d}}$ \\
\hline T9 & $6.5^{\mathrm{a}}$ & $32.2^{\mathrm{b}}$ & $0.8^{\mathrm{ab}}$ & $10.3^{\mathrm{a}}$ & $12.1^{\mathrm{bc}}$ & $0.6^{\mathrm{ef}}$ & $5.2^{\mathrm{abc}}$ \\
\hline $\mathrm{T} 10$ & $6.2^{\mathrm{b}}$ & $22.8^{\mathrm{b}}$ & $0.9^{\mathrm{a}}$ & $10.4^{\mathrm{a}}$ & $11.4^{\mathrm{c}}$ & $0.5^{\mathrm{fg}}$ & $6.3^{\mathrm{a}}$ \\
\hline $\mathrm{T} 11$ & $6.1^{\mathrm{b}}$ & $31.1^{\mathrm{b}}$ & $0.7^{\text {bcde }}$ & $9.4^{\mathrm{ab}}$ & $14.2^{\mathrm{ab}}$ & $0.8^{\mathrm{cd}}$ & $3.9^{\mathrm{bcd}}$ \\
\hline $\mathrm{T} 12$ & $6.0^{\mathrm{b}}$ & $45.1^{\mathrm{a}}$ & $0.8^{\mathrm{ab}}$ & $10.0^{\mathrm{a}}$ & $13.4^{\mathrm{abc}}$ & $0.9^{\mathrm{bc}}$ & $5.5^{\mathrm{abc}}$ \\
\hline C.V & 3.4 & 29.3 & 16.77 & 11.46 & 13.2 & 15.3 & 40.9 \\
\hline
\end{tabular}

T1: control, T2: effective microorganisms, T3; reference fertiliser, T4; reference fertiliser + EM, T5; compost alone, T6: compost + effective microorganisms, T7: half reference fertiliser + compost, T8: half reference fertiliser + compost + effective microorganisms, T9: goat manure alone, T10: goat manure + effective microorganisms, T11; half reference fertiliser + goat manure, T12; goat manure + half reference fertiliser + effective microorganisms

Means in a column with a different letter are statistically different (LSD test; $p \leq 0.05$ )

The highest EC value was observed in plots where the reference fertiliser was applied. A similar pattern was observed in respect of the application of sole goat manure or goat manure in combination with half the reference fertiliser, with or without EM.

There were significant $(\mathrm{p} \leq 0.05)$ treatment effects on residual soil $\mathrm{N}$ concentration (Table 4), although the values did not significantly differ from the initial concentration. Soil $\mathrm{N}$ levels associated with the reference fertiliser, half the reference fertiliser + compost + EM, goat manure, goat manure + EM, half the reference fertiliser + goat manure, and half the reference fertiliser + goat manure + EM were significantly higher than those of the control treatment, suggesting that the plants did not exhaust $\mathrm{N}$ from these added amendments (Table 3). The increase in $\mathrm{N}$ that was observed could possibly be due to the slow release of nutrients through mineralisation from these organic materials. The application of goat manure + EM resulted in the highest soil $\mathrm{N}$ and $\mathrm{C}$ contents, suggesting that EM increased the mineralisation of goat manure applied to the soil.

A similar trend was observed with soil $\mathrm{C}$, and the greatest amounts of soil $\mathrm{N}$ and $\mathrm{C}$ were observed in soils treated with goat manure and EM together. The observed decrease in the soil $\mathrm{C}: \mathrm{N}$ ratio indicated a build-up of the $\mathrm{N}$ pool in the soil. The application of different amendments decreased extractable soil $\mathrm{P}$ to below initial levels. The highest extractable $\mathrm{P}$ was observed in respect of the application of reference fertiliser, suggesting that the crop had not exhausted the soil P from the fertiliser that had been applied.

Soil residual $\mathrm{K}$ in pots treated with goat manure, goat manure + EM and half the reference fertiliser + goat manure, and EM was significantly higher than that of the control treatment. The highest soil residual $\mathrm{K}$ was observed in pots where goat manure 
was applied with EM, although the manure used had a relatively low concentration of $\mathrm{K}$. Kraal manure has, on average, about $2 \% \mathrm{~K}$, which is far higher than the $0.5 \%$ contained in the goat manure used (Bornman et al. 1989; Kizzar et al., 2010; Materechera and Mkhabela, 2016). General residual soil $\mathrm{K}$ in all the amendments exceeded the critical level of $80-120 \mathrm{mg} \mathrm{kg}^{-1}$ suggested by Bornman et al. (1989). Results from this study are consistent with what was reported by Laker (1976) and Ayanda et al. (2016), namely, that most South African soils are not deficient in K.

\section{Conclusion}

EM application had inconsistent effects on Swiss chard yields. The use of goat manure with a narrower $\mathrm{C}: \mathrm{N}$ ratio than the compost used in earlier studies did not improve EM effectiveness, indicating that the observed ineffectiveness of EM was not related to the quality of the organic material used. However, the results of this study show the benefits of the combined application of organic amendments with half of the recommended mineral fertiliser over the separate full application of inorganic fertiliser or organic amendment.

\section{REFERENCES}

[1] Ahn, K., Lee, K.B., Kim, Y.J., Koo, Y.M. (2014): Quantitative analysis of the three main genera in effective microorganisms using qPCR. -Korean Journal Chemical Engineering 31: 849-854.

[2] Ayanda, K., Beyene, ST., Mlambo, V., Mopipi, K. (2016): Mineral concentration and standing crop yield dynamics of forages in semi-arid communal grazing lands of South Africa: effect of landscape and season. -Animal and feed technology 16: 209-226.

[3] Bajwa, R., Javaid, A., Tasneem, Z. (1995): Response of indigenous soil microflora to EM inoculation in Pakistan. -Biota 1: 73-79.

[4] Bajwa, R., Javaid,A., Rabbani, N. (1999): EM and VAM technology in Pakistan. VIII: Effect of organic amendments and effective microorganisms (EM) on VA mycorrhiza, nodulation and crop growth. Trifolium alexandrianum L. -Pakistan Journal of Biological Sciences 2: 590-593.

[5] Bell, T.H., Yergeau, E., Maynard, C., Juck, D., Whyte, L.G., Greer, C.W. (2013): Predictable bacterial composition and hydrocarbon degradation in Arctic soils following diesel and nutrient disturbance. -ISME Journal 7: 1200-1210.

[6] Bhalla, A., Bansal, N., Kumar, S., Bischoff, K.M., Sani, R.K. (2013): Improved lignocellulose conversion to biofuels with thermophilic bacteria and thermostable enzymes. -Bioresource Technology. 128: 751-759.

[7] Boechat, C.L., Santos, J.A.G., Accioly, A.M.de A. (2013): Net mineralization nitrogen and soil chemical changes with application of organic wastes with 'Fermented Bokashi Compost'. Acta Scientiarum. -Agronomy 35: 257-264.

[8] Boga, C., Vecchio, E.D., Forlani, L., Franceschetti, M. (2014): Microbes to clean indoor pollutants. -Environmental Chemistry Letters 12: 429-434.

[9] Bornman, J., Ran, J., Well, J. F., Venter, G.C.H., Vosloo L. B. (1989): FSSA fertilizer handbook. The Fertilizer Society of South Africa. -Hennopsmeer, South Africa.

[10] Bouws, H., Finckh, M. R. (2008): Effects of strip intercropping of potatoes with nonhosts on late blight severity and tuber field in organic production. -Plant Pathology 57: 916-927. 
[11] Carvalho, A.M., de Coelho, M.C., Dantas, R.A., Fonseca, O.P., Júnior, R.G., Figueiredo, C.C. (2013): Chemical composition of cover plants and its effect on maize yield in notillage systems in the Brazilian savanna. -Crop Pasture Science 63: 1075-1081.

[12] Cooke, G. W. (1972): Organic manures and fertilizers in fertilizing for maximum yield. Lockwood and Son Ltd, London.

[13] Daly, M. J., Stewart, D.C.P. (1999): Influence of effective microorganisms on vegetable production and carbon mineralization - a preliminary investigation. -Journal of Sustainable Agriculture 14: 15-28.

[14] Daur, I. (2015): Study of commercial effective microorganism on composting and dynamics of plant essential metal micronutrients. -Journal of Environmental Biology 37: 937-941.

[15] Daur, I. (2016): organic alfalfa production using different em.1 composts. -Turkish Journal of Field Crops 21: 139-147.

[16] Daur, I., Abusuwar, A.O., Alghabari, F. (2015): Exploitation of em.1-treated blend of organic Resources and humic acid for organic berseem (Trifolium alexandrinum L.) production. -Turkish Journal of Field Crops 20: 125-130.

[17] Elfatih, M., Rahman, A., Mutanga, O., Odindi, J., Elhadi, A., Odindo, A., Riyad, I. (2014): A comparison of partial least squares (PLS) and sparse PLS regressions for predicting yield of Swiss chard grown under different irrigation water sources using hyperspectral data. -Computers and Electronics in Agriculture 106: 1-19.

[18] Fu,Y., Li, H., Yu, J., Liu, H., Cao, Z., Manukovsky, N.S., Liu, H. (2017): Interaction effects of light intensity and nitrogen concentration on growth, photosynthetic characteristics and quality of lettuce (Lactuca sativa L. Var. youmaicai). -Scientia Horticulturae 214: 51-57.

[19] Gishangi, E., Mnkeni, P.N.S., Brookes, P.C. (2010): Effects of goat manure and inorganic phosphate addition on soil inorganic and microbial biomass phosphorus fraction under laboratory incubation conditions. -Soil Science and Plant Nutrition 55: 764-771.

[20] Groenestein, C. M., Van Faasen, H. G. (1996): Volatilization of ammonia, nitrous oxide and nitric oxide in deep litter systems for fattening pigs. -Journal of Agricultural Engineering Research 65: 269-274.

[21] Herencia, J.F., Maqueda, C. (2016): Crops and soils research paper effects of time and dose of organic fertilizers on soil fertility, nutrient content and yield of vegetables. Journal of Agricultural Science 154: 1343-1361.

[22] Hu, C., Qi, Y. (2013): Long-term effective microorganisms application promote growth and increase yields and nutrition of wheat in China. -European Journal of Agronomy 46: 63-67.

[23] Hussain, T., Javaid, T., Parr,J. F., Jilam, G., Haq. M. A. (1999): Rice and wheat production in Pakistan with effective microorganisms. -American Journal of Alternative Agriculture 14: 30-36.

[24] Iwaishi, S. (2000): Effect of organic fertilizer and effective microorganisms on growth, yield and quality of paddy-rice varieties. -Journal of Crop Production 3: 269-273.

[25] Javaid, A. (2009): Growth, nodulation and yield of black gram [Vigna mungo (L) Hepper] as influenced by biofertilizers and soil amendments. -African Journal of Biotechnology 8: 5711-5717.

[26] Javaid, A. B. (2010): Beneficial microorganisms for sustainable agriculture. -In: Lichtfouse, E. (ed) Genetic engineering, biofertilization, soil quality and organic farming, sustainable agriculture reviews - 4. Springer Publishers, Netherlands.

[27] Javaid, A., Bajwa, R. (2011): Field evaluation of effective microorganisms (EM) application for growth, nodulation, and nutrition of mung bean. -Turkish Journal of Agriculture and Forestry 35: 443-452.

[28] Javaid, A., Bajwa, R. (2011b): Field evaluation of effective microorganisms (EM) application for growth, nodulation, and nutrition of mung bean. -Turkish Journal Agriculture Forestry 35: 443-452. 
[29] Javaid, A., Bajwa, R., Anjum, T. (2002): EM and VAM technology in Pakistan, XII: Growth, nodulation and VA mycorrhizal response of Phaseolus vulgaris to long term EM application. -Pakistan Journal of Phytopathology 14: 57-61.

[30] Javaid, A., Siddiqi, I., Banjwa, R. (2000): EM and VAM technology in Pakistan. X: Effect of long term application of EM on growth, yield and VA mycorrhiza colonization in wheat (Triticum aestivum L). -Pakistan Journal of Phytopathology 12:57-61.

[31] Jones, J. B. (Jr)., R. L. Large., D. B. Pfleiderer, and H. S. Klosky. (1971): How to properly sample for a plant analysis. - In: Jones, J. B. (JR)., Case, V. W. (eds) Soil testing and plant analysis, $3^{\text {rd }}$ edition. Soil Science Society of America, Madison, WI , USA.

[32] Khaliq, A., Abbas, M. K., Hussain, T. (2006): Effects of integrated use of organic and inorganic nutrient sources with effective micro-organisms (EM) on seed cotton yield in Pakistan. -Bioresource Technology 97: 967-972.

[33] Khan, S., Afzal, M., Iqbal, S., Khan, Q., M. (2013): Plant-bacteria partnerships for the remediation of hydrocarbon contaminated soils. -Chemosphere 4: 1317-1332.

[34] Khuc, T.H., Do, T.T.V., Inger L.E., W., Spörndly, E. (2012): Effect of Harvesting Frequency, Variety and Leaf Maturity on Nutrient Composition, Hydrogen Cyanide Content and Cassava Foliage Yield. -Asian-Australas Journal of Animal Science 25: 1691-1700.

[35] Laker, M. C. (1976): Soil fertility and the potential for increased crop production in the South African homelands. -Fertilizer Society of South Africa Journal 2: 21-24.

[36] LECO CORPORATION (2003). TRUSPEC CN carbon/nitrogen determinator. Instruction manual. LECO Corporation, St Joseph, MI.

[37] Mandiringana, O. T., Mnkeni. P. N. S., Mkile, Z., Van Averbeke, W., Van Ranst, E., Verplancke, H. (2005): Mineralogy and fertility status of selected soils of the Eastern Cape Province, South Africa. -Communications in Soil Science and Plant Analysis 36: 2431-2446.

[38] Marais, J. N., Brutsch, M.O. (1994): The Ehlers system of assessing the suitability of temperature regime of a region for crop production. Paper presented at the 1994 SASHS Congress, Nelspruit, South Africa.

[39] Materechera, S.A, Mkhabela, T.S. (2016): Influence of land use on properties of a fertile soil under low external input farming in southeastern Swaziland. -Soil and tillage research 62: 15-25.

[40] Mayer, J., Scheid, S., Widmer, F., Fließbach, A., Oberholzer, H. (2010): How effective are 'Effective microorganisms ${ }^{\circledR}(\mathrm{EM})$ '? Results from a field study in temperate climate. Applied Soil Ecology 46: 230-239.

[41] Mayera, J., Scheida, S., Widmera, F., Fließbachb, A., Oberholzera, H.R. (2010): How effective are 'Effective microorganisms ${ }^{\circledR}(\mathrm{EM})$ '? Results from a field study in temperate climate. -Applied Soil Ecology 46: 230-239.

[42] Megal, L., Glauser, G., Rasmann, S. (2014): Fertilization with beneficial microorganisms decreases tomatodefenses against insect pests. -Agronomy for Sustainable Development 34:649-656.

[43] Mhlontlo, S., Muchaonyerwa, P., Mnkeni, P. N. S. (2007): Effects of sheep kraal manure on growth, dry matter yield and leaf nutrients composition of a local amaranthus accession in the central region of the Eastern Cape Province, South Africa. -Water SA. 33: 363-368.

[44] Ncube, L., Brutsch. M. O. (2012): Effects of the integrated use of effective microorganisms, compost and mineral fertilizer on greenhouse-grown tomato. -African Journal of Plant Science 6: 120-124.

[45] Ncube, L., Mnkeni, P. N. S., Brutsch, M. O. (2011): Agronomic suitability of effective micro-organisms for tomato production. -African Journal of Agricultural Research 6: $650-654$. 
[46] Neina, D., Buerkert, A., Joergensen, R.G. (2016b): Microbial response to restoration of a technosol with local organic amendments. - Soil Tillage Res. 163: 214-223.

[47] Neina, D., Buerkert, A., Rainer Georg Joergensen, R.G. (2016a): Potential mineralizable $\mathrm{N}$ and $\mathrm{P}$ mineralization of local organic materials in tantalite mine soils. -Applied Soil Ecology 108: 211-220.

[48] Non-affiliated Soil Analysis Working Group. (1990): Handbook of standard soil testing methods for advisory purposes. - Soil Science Society of South Africa, Pretoria.

[49] Okalebo, J. R., Gathua, K. W., Woomer, P. L. (2002): Laboratory methods for soil and plants analysis: A working manual. $2^{\text {nd }}$ edition. - Tropical Soil Fertility and Biology program, Nairobi, Kenya.

[50] Soil Working Group (1991). Soil classification: A taxonomic system for South Africa. Memoirs on the agricultural natural resources of South Africa No 15. - Department of Agricultural Development, Pretoria, South Africa.

[51] Tanner, P. D., Mugwira, L. (1984): Effectiveness of communal area manures as sources of nutrients for young maize plants. -Zimbabwe Agriculture Journal 81: 31-35.

[52] Valarini, P. J., Alveraz, M. C. D., Gasco, J. M., Guerrero, F., Tokeshi, H. (2002): Integrated evaluation of soil quality after the incorporation of organic matter and microorganisms. -Brazilian Journal of Microbiology 33:35-40.

[53] Van Vliet, P. C. J., Bloem, J., De Goede, R. G. M. (2006): Microbial diversity, nitrogen loss and grass production after addition of effective microorganisms (R) (EM) to slurry manure. -Applied Soil Ecology 32: 188-198.

[54] $\mathrm{Xu}, \mathrm{H}$. L. (2000): Effects of microbial inoculant and organic fertilizer on the growth, photosynthesis and yield of sweet corn. - Journal of Crop Production 3: 173-183.

[55] Xu, J., Xu, X., Liu, Y., Li, H., Liu, H. (2016): Effect of microbiological inoculants DN-1 on lignocellulose degradation during cocomposting of cattle manure with rice straw monitored by FTIR and SEM. -Environmental Progress and Sustainable Energy 35: 345351.

[56] Yamada, K., Xu, H. L. (2000): Properties and applications of an organic fertilizer inoculated with effective microorganisms. -Journal of Crop Prod. 3: 255-268.

[57] Zhao, N., He, N.N., Wang, Q., Zhang, X., Xu, Z., Yu, G. (2014): The altitude patterns of leaf $\mathrm{C}: \mathrm{N}: \mathrm{P}$ stoichiometry are regulated by plant growth from, climate and soil on Changbai Mountain, China. -PLOS One 9: e95196. 